\title{
防災計画のための空間被害分布分析*
}

\section{Spatial Economic Damage Assessment for Disaster Prevention Plan*}

小池淳司**・山田勝也***

By Atsushi KOIKE** • Katsuya YAMADA***

\section{1 はじめに}

わが国では，台風や地震等の災害が世界的に見ても 多く発生する自然環境にあり，毎年のように災害による 社会資本一の被害が起きている．特に，道路に代表され る交通施設への被害は，地域間の交流・交易を停止また は困難にさせ，その影響は直接被害のみならず，間接被 害という形で全国に波及する。したがって，交通施設の 維持管理や防災対策等を適切に実施することは，災害に よる経済被害を軽減する上で重要である。一方で，交通 施設の維持管理を完全にすることは不可能であるという 現状がある限り，これを前提として，交通施設の維持管 理に対する方策を立てなければならない，そのため，交 通施設の維持管理を集権的に行うか分権的に行うかは, 交通施設の維持管理方策を決定する上で重要な要素とな りえる，それは，被害の波及効果をともなう交通施設の 維持管理方策を決定する際には，計画主体の違いにより 維持管理を行う交通施設の重要度, 維持管理の優先順位 が異なると考えられるためである.

そこで本研究では，わが国の道路施設を対象として， 道路施設の機能が低下した場合の経済への影響を空間的 応用一般均衡モデル(以下，SCGEモデル)により評価する ことで，道路施設の重要度，維持管理の優先順位につい て検討する．道路をはじめとする交通施設の機能低下に よる影響をSCGEモデルにより評価しようとする研究には, 筆者ら ${ }^{1)-2)}$ のグループのほかに土屋・多々納・岡田らの 研究3)-4)が挙げられる。 それらでは，SCGEモデルを用い て，大規模地震による当該地域での交通施設損傷がもた らす交通費用の増加を外的ショックとして与え，自地域 及びその他地域経済一の影響を評価しようとしている。 また，わが国では地方分権の動きがあるため，本研究で は，道路施設の維持管理計画主体として都道府県と国を 想定することで，維持管理計画主体別に道路施設の機能

*キーワーズ : 維持管理計画、防災計画

**正員、工博、鳥取大学工学部社会開発システム工学科

（=680-8552 鳥取県鳥取市湖山町南4-101、

TEL:0857-31-5313、E-mail:koike@sse. tottori-u. ac. jp) ***正員、株式会社ライテック 社会・公共ソリューション部
低下による空間被害分布を分析する．これにより，地方 分権下のわが国の道路施設に対して，事前に道路施設の 重要度，維持管理の優先順位を明らかにすることを試み る. なお，実証分析において，基準データセットには平 成 7 年(1995年) 47都道府県産業連関表5) を用いた。地域 区分は47都道府県，産業区分は 3 区分（第 1 次産業，第 2 次産業，第 3 次産業）とした.

\section{$2 \quad$ SCGEモデルの概要}

（1） モデルの前提条件

(1) 社会経済には企業・家計の 2 主体が存在する.

(2) $S$ 地域に分割された閉じた経済空間を想定する. ただし， $s \in \mathbf{S}=\{1, \cdots, s, \cdots, S\} \quad(R$ も同様 $)$

(3) 各地域には $J$ 種類の生産財が存在し，それぞれに 代表的企業が 1 つ存在する. また，各地域には 1 つの代表的家計が存在する. ただし,$j \in \mathbf{J}=\{1, \cdots, j, \cdots, J\} \quad(I$ も同様 $)$

(4) 各地域での生産財はまったく異なるものである. (Armingtonの仮定)

(5) 財の輸送はiceberg型の輸送構造である.

(6) 生産要素市場は労働と資本であり, それら生産要 素市場は各地域で閉じている.

(7) 市場は完全競争的であり，長期的均衡状態にある.

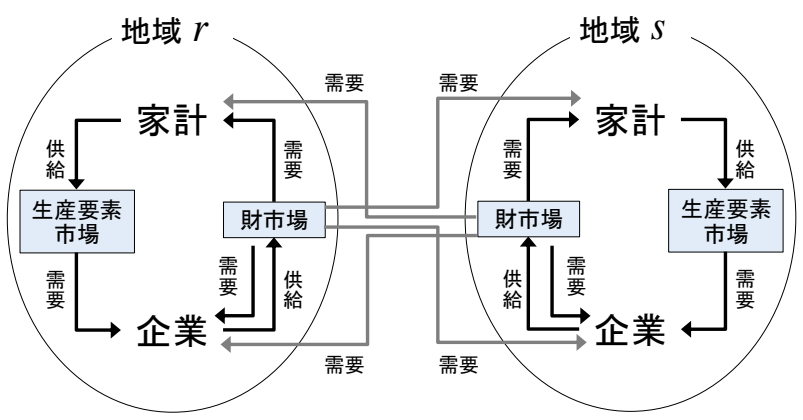

図 1 モデルの概略

（2） 道路施設の機能低下

本研究では，道路施設の機能低下を交易抵抗の増加と 捉え，以下のように財の生産地価格と消費地価格の乘離 によって表現する. 


$$
P_{i}^{r s}=\left(1+t^{r s}\right) P_{i}^{r}
$$

ただし, $P_{i}^{r s}$ : 地域 $r$ の企業 $i$ の財を地域 $s$ の家計・企 業が購入する際の価格(消費地価格),$P_{i}^{r}$ : 地域 $r$ の企 業 $i$ の財の価格(生産地価格), $t^{r s}$ : マークアップ率

\section{（3）企業の行動}

地域 $s$ の生産物 $j$ を生産する企業 $j$ は, Nested-CES型 の生産構造を持ち, 自地域と他地域で生産された中間財 と, 労働・資本からなる生産要素を用いて財を生産寸る. まず，生産関数をLeontief型で定式化する.

$$
X_{j}^{s}=\min \left(\frac{V A_{j}^{s}\left(l_{j}^{s}, k_{j}^{s}\right)}{a_{0 j}^{s}}, \frac{x_{1 j}^{s}}{a_{1 j}^{s}}, \frac{x_{2 j}^{s}}{a_{2 j}^{s}}, \cdots, \frac{x_{I j}^{s}}{a_{I j}^{s}}\right)
$$

ただし, $X_{j}^{s}$ : 地域 $s$ 企業 $j$ の生産量, $l_{j}^{s}$ : 地域 $s$ 企業 $j$ の労働投入量, $k_{j}^{s}$ : 地域 $s$ 企業 $j$ の資本投入量, $x_{i j}^{s}$ : 企業 $i$ から地域 $s$ の企業 $j$ 一投入される中間財の 合成財, $V A_{j}^{s}$ : 地域 $s$ 企業 $j$ の付加価值, $a_{i j}^{s}$ : 投入係 数, $a_{0 j}^{s}:$ 付加価值比率

次に付加価值について, 付加価值関数をCobb-Douglas 型で仮定し，生産技術制約下での費用最小化行動として 以下のように定式化する。

$$
\begin{aligned}
& \min _{l_{j}^{s}, k_{j}^{s}} w^{s} l_{j}^{s}+r^{s} k_{j}^{s} \\
& \text { s.t. } \quad V A_{j}^{s}=\eta_{j}^{s} l_{j}^{s \alpha_{j}^{s}} k_{j}^{s 1-\alpha_{j}^{s}}=1
\end{aligned}
$$

ただし, $w^{s}$ : 地域 $s$ の賃金率, $r^{s}$ : 地域 $s$ の資本レン 卜, $\eta_{j}^{s}$ : 効率パラメータ, $\alpha_{j}^{s}:$ 分配パラメータ

(3)式より，付加価值一単位あたりの労㗢と資本の需 要量 $D_{l j}^{s}, D_{k j}^{s}$ が求まる.

$$
\begin{aligned}
D_{l j}^{s} & =\frac{\alpha_{j}^{s}}{w^{s}} \frac{1}{\eta_{j}^{s}}\left(\frac{w^{s}}{\alpha_{j}^{s}}\right)^{\alpha_{j}^{s}}\left(\frac{r^{s}}{1-\alpha_{j}^{s}}\right)^{1-\alpha_{j}^{s}} \\
D_{k j}^{s} & =\frac{1-\alpha_{j}^{s}}{r^{s}} \frac{1}{\eta_{j}^{s}}\left(\frac{w^{s}}{\alpha_{j}^{s}}\right)^{\alpha_{j}^{s}}\left(\frac{r^{s}}{1-\alpha_{j}^{s}}\right)^{1-\alpha_{j}^{s}}
\end{aligned}
$$

中間財の合成財についても同様に，中間財投入制約 下での費用最小化行動として以下のように定式化する. ここでは中間財の合成財の生産関数をCES型で仮定する.

$$
\begin{aligned}
& \min _{x_{i j}^{s s}} \sum_{r \in \mathbf{R}}\left(1+t^{r s}\right) P_{i}^{r} x_{i j}^{r s} \\
& \text { s.t. } \quad x_{i j}^{s}=\phi_{i j}^{s}\left(\sum_{r \in \mathbf{R}} \beta_{i j}^{r s} x_{i j}^{r s-\frac{\varphi-1}{\varphi}}\right)^{\frac{\varphi}{\varphi-1}}=1
\end{aligned}
$$

ただし， $P_{i}^{r}$ : 地域 $r$ での財 $i$ の価格， $x_{i j}^{r s}$ : 地域 $r$ から 地域 $S$ の企業 $j$ 一投入される中間投入財 $i, \phi_{i j}^{s}$ : 効率 パラメータ, $\beta_{i j}^{r s}$ : 分配パラメータ, $\varphi$ : 代替弾力性
(6)式より, 中間財の合成財一単位あたりの中間財需 要量 $c x_{i j}^{r s}$ が求まる.

$$
c x_{i j}^{r s}=\frac{1}{\phi_{i j}^{s}}\left[\frac{\beta_{i j}^{r s}}{\left(1+t^{r s}\right) P_{i}^{r}}\right]^{\varphi}\left[\sum_{r \in \mathbf{R}} \beta_{i j}^{r s \varphi}\left[\left(1+t^{r s}\right) P_{i}^{r}\right]^{1-\varphi}\right]^{\frac{\varphi}{1-\varphi}}
$$

また，(6) 式の最適化問題をラグランジュ未定乗数法 により解く際のラグランジュ乗数より, 中間財の合成財 価格 $P I_{i j}^{s}$ が決定される.

$$
P I_{i j}^{s}=\frac{1}{\phi_{i j}^{s}}\left[\sum_{r \in \mathbf{R}} \beta_{i j}^{r s \varphi}\left[\left(1+t^{r s}\right) P_{i}^{r}\right]^{1-\varphi}\right]^{\frac{1}{1-\varphi}}
$$

さらに，企業の生産関数は規模に対して収穫一定で あるため，企業に超過利潤が存在せず，企業が生産する 財の価格は限界費用と平均費用に等しくなる. 寸なわち, 以下の式が成立する.

$$
\begin{aligned}
P_{j}^{s}= & a_{0 j}^{s}\left(w^{s} D_{l j}^{s}+r^{s} D_{k j}^{s}\right) \\
& +\sum_{i^{\prime} \in \mathbf{I}} a_{i j}^{s} \frac{1}{\phi_{i j}^{s}}\left[\sum_{r \in \mathbf{R}} \beta_{i j}^{r s \varphi}\left[\left(1+t^{r s}\right) P_{i}^{r}\right]^{1-\varphi}\right]^{\frac{1}{1-\varphi}}
\end{aligned}
$$

\section{（4）家計の行動}

地域 $s$ には代表的な家計が存在し, Nested-CES型の消 費構造を持つと仮定する．まず，消費財の合成財の代替 関係をCES型で表現し，家計の予算制約下での効用最大 化行動として以下のように定式化する.

$$
\begin{aligned}
& V^{s}=\max _{f_{i}^{s}}\left(\sum_{i \in \mathbf{I}} \gamma_{i}^{s} f_{i}^{\frac{\sigma_{1}-1}{\sigma_{1}}}\right)^{\frac{\sigma_{1}}{\sigma_{1}-1}} \\
& \text { s.t. } \sum_{i \in \mathbf{I}} P F_{i}^{s} f_{i}^{s}=w^{s} L^{s}+r^{s} K^{s}-C A^{s}
\end{aligned}
$$

ただし， $V^{s}$ : 間接効用， $f_{i}^{s}$ : 地域 $s$ の家計の企業 $i$ の 消費財の合成財消費量, $L^{s}$ : 地域 $s$ 労働供給量, $K^{s}$ : 地域 $s$ の資本供給量, $P F_{i}^{s}$ : 地域 $s$ の家計が直面 寸る企業 $i$ の消費財の合成財価格，CA : 域際収支黒字 額, $\gamma_{i}^{s}$ : 地域 $s$ の家計の企業 $i$ の消費財の合成財に関 する支出割合係数, $\sigma_{1}$ : 代替弾力性

(10)式より, 消費財の合成財の需要量 $f_{i}^{s}$ が求まる.

$$
f_{i}^{s}=\left(\frac{\gamma_{i}^{s}}{P F_{i}^{s}}\right)^{\sigma_{1}} \frac{w^{s} L^{s}+r^{s} K^{s}-C A^{s}}{\sum_{i \in \mathbf{I}} \gamma_{i}^{s \sigma_{1}} P F_{i}^{s 1-\sigma_{1}}}
$$

次に，自地域と他地域の消費財の代替関係をCES型で 表現し, 家計の消費財の合成財消費制約下での効用最大 化行動として以下のように定式化する.

$$
\begin{aligned}
& \left.V_{i}^{\prime s}=\max _{f_{i}^{r s}} \cdot\left(\sum_{r \in \mathbf{R}} \gamma_{i}^{r s} f_{i}^{r s}\right)^{r s}{ }^{\frac{\sigma_{2}-1}{\sigma_{2}}}\right)^{\frac{\sigma_{2}}{\sigma_{2}-1}} \\
& \text { s.t. } P F_{i}^{s} f_{i}^{s}=\sum_{r \in \mathbf{R}}\left(1+t^{r s}\right) P_{i}^{r} f_{i}^{r s}
\end{aligned}
$$


ただし， $V_{i}^{\prime s}$ : 間接効用, $f_{i}^{r s}$ : 地域 $s$ の家計が消費す る地域 $r$ 企業 $i$ の生産財消費量, $\gamma_{i}^{r s}$ : 地域 $s$ の家計の 地域 $r$ 企業 $i$ の生産財消費に関寸る支出割合係数, $\sigma_{2}:$ 代替弾力性

（12）式より，消費財の合成財一単位あたりの消費財需 要量 $c f_{i}^{r s}$ が求まる.

$$
c f_{i}^{r s}=\left[\frac{\gamma_{i}^{r s}}{\left(1+t^{r s}\right) P_{i}^{r}}\right]^{\sigma_{2}} \frac{P F_{i}^{s}}{\sum_{r \in \mathbf{R}} \gamma_{i}^{r s} \sigma_{2}\left[\left(1+t^{r s}\right) P_{i}^{r}\right]^{1-\sigma_{2}}}
$$

また，(12)式の最適化問題をラグランジュ未定乗数法 により解く際のラグランジュ乗数の逆数より, 消費財の 合成財価格 $P F_{i}^{r}$ が求まる.

$$
P F_{i}^{s}=\left[\sum_{r \in \mathbf{R}} \gamma_{i}^{r s \sigma_{2}}\left[\left(1+t^{r s}\right) P_{i}^{r}\right]^{1-\sigma_{2}}\right]^{\frac{1}{1-\sigma_{2}}}
$$

\section{（5）市場均衡条件}

本モデルでは企業の生産関数を規模に関して収穫一定 を仮定しているため, 企業は常に需要に見合うだけの生 産を行う. 寸なわち, 常に以下の式が成立する.

$$
X_{i}^{r}=\sum_{s \in \mathbf{S}} \sum_{j \in \mathbf{S}}\left(1+t^{r s}\right) x_{i j}^{r s}+\sum_{s \in \mathbf{S}}\left(1+t^{r s}\right) f_{i}^{r s}
$$

したがって, 以下の生産要素市場のみが市場均衡条件 として意味を持つ.

$$
\begin{aligned}
& \sum_{j \in \mathbf{J}} a_{0 j}^{s} X_{j}^{s} D_{l j}^{s}\left(w^{s}, r^{s}\right)=L^{s} \\
& \sum_{j \in \mathbf{J}} a_{0 j}^{s} X_{j}^{s} D_{k j}^{s}\left(w^{s}, r^{s}\right)=K^{s}
\end{aligned}
$$

（6）経済被害の定義

経済被害は，等価変分(Equivalent Variation)により 家計の厚生水準の変化を測ることで求める.

$$
E V^{s}=\left(w_{0}^{s} L^{s}+r_{0}^{s} K^{s}-C A^{s}\right)\left(\frac{U_{1}^{s}-U_{0}^{s}}{U_{0}^{s}}\right)
$$

ただし， $E V^{s}$ : 地域 $s$ の経済被害 (便益)， $U^{s}$ : 地域 $s$ の家計の効用, $0,1:$ 道路施設の機能低下前後を表す

（7） 道路ネットワークと維持管理シナリオ

本研究では図 2 に示寸道路ネットワークを分析対象 とする.ノードには各都道府県の主要都市を, リンクに は各都道府県の主要都市間を結ぶ主要国道, または高速 道路を想定している. また, 道路施設について地域内道 路と地域間道路の 2 種類を想定する. 具体的には, 地域 内道路とは，ある地域における自地域内の道路施設であ り, 地域間道路とは自地域と他地域とを結ぶ道路施設で ある. 図2ではノードが地域内道路を意味しており,リ ンクが地域間道路を意味している.

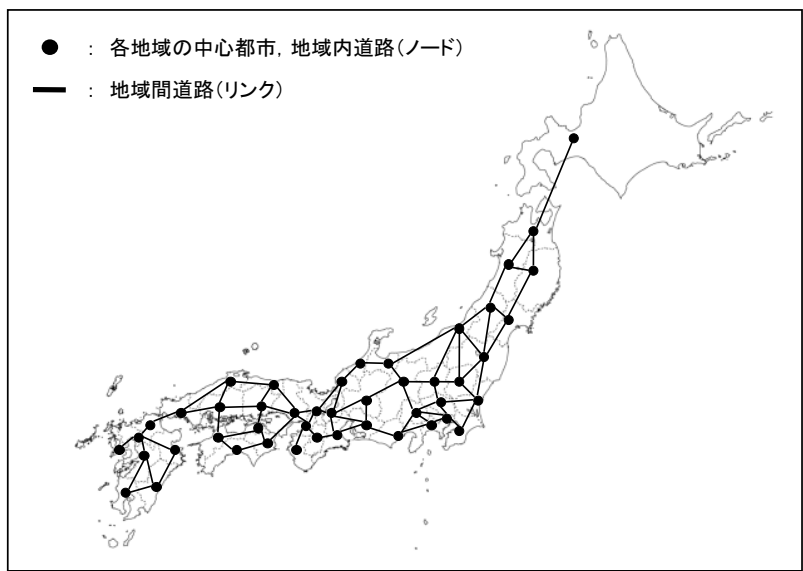

図2 分析対象とする道路ネットワーク

なお，この 2 種類の道路施設は互いに独立しており， 一方の道路の所要時間の変化がもう一方の道路の所要時 間に影響を与えないと仮定する。このような 2 種類の道 路施設を維持管理するかどうかに関する組み合わせは,

\begin{tabular}{|c|c|c|c|}
\hline & \multicolumn{2}{|c|}{ 地域間道路 } \\
\hline & & 維持管理寸る & 維持管理しない \\
\hline \multirow{4}{*}{ 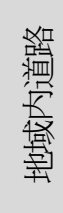 } & 維持管理 & $\left(a_{0}, b_{0}\right)=(0,0)$ & $\left(a_{1}, b_{1}\right)$ \\
\hline & する & CASE0 & CASE1 \\
\hline & 維持管理 & $\left(a_{2}, b_{2}\right)$ & $\left(a_{3}, b_{3}\right)$ \\
\hline & しない & CASE2 & CASE3 \\
\hline
\end{tabular}
表 1 のよう表わされる. また, 表 1 の維持管理の組み 合わせをもとに，表 2 のよな経済被害行列を作成する.

\section{表 1 道路施設の維持管理の組み合わせ}

\begin{tabular}{|c|c|c|}
\hline & 地域内道路 & 地域間道路 \\
\hline CASE0 & $\bigcirc$ & $\bigcirc$ \\
\hline CASE1 & $\bigcirc$ & $\times$ \\
\hline CASE2 & $\times$ & $\bigcirc$ \\
\hline CASE3 & $\times$ & $\times$ \\
\hline
\end{tabular}

表 2 経済被害行列

ここで，表 2 に示寸経済被害行列について次の仮定 を設ける.

(1) 利得行列における利得を道路施設の機能低下による 被害額で表現し，これを経済被害行列と呼ぶ。

(2) 道路施設の維持管理が適切に行われていれば, 道路 施設の機能低下による経済被害を 0 と考える.

(3) $a_{i}$ は自地域での被害額とし， $b_{i}$ はその他地域の被 害額とする. $i$ はどの CASE かを示す.

また, 経済被害行列ではプレイヤーが決まっておら ず，経済被害行列より，道路施設の維持管理計画主体が, 集権的あるいは分権的という条件下でどのような戦略を とるかを考察していく，なお，表 2 に示寸経済被害行列 
は, 地域内道路と地域間道路の両方を単一のプレイヤー が維持管理する場合, ゲームの状況とはならないため, ゲーム理論における利得行列を厳密には意味していない．

表 1 の各ケースが，具体的にどういう状況であるか を考察する. まずCASEO は, 地域内道路も地域間道路も 維持管理がされるというケースである. 具体的には, 十 分な予算を有する維持管理計画主体が, 全ての道路施設 の維持管理を実施するという状況が考えられる. 次に CASE1 は, 地域間道路の維持管理を行わず, 地域内道路 の維持管理を行うというケースである. 具体的には, 利 己的な維持管理計画主体が自地域の道路施設により投資 を行う状況が考えられる. 次に CASE2 は, 地域内道路の 維持管理を行わず，地域間道路の維持管理を行うという ケースである. 具体的には, 交易が多い地域間道路の多 重化を行うなど，地域間道路により投資を行う状況が考 えられる. 最後にCASE3 は, 地域内道路も地域間道路も 維持管理がされないというケースである. 具体的には, 維持管理計画主体に道路施設の維持管理に対する予算が 全くないという状況が考えられる.ここで問題となるの は, CASE1 と CASE2 である. それは, CASE0 と CASE3 で は道路施設の維持管理水準が維持管理計画主体に依存し ないと考えられる一方で, CASE1 と CASE2 では, 道路施 設の維持管理計画主体の違いにより, 地域内道路と地域 間道路の重要度, 維持管理の優先順位が異なると考えら れるためである.

本研究では, 道路施設が適切に維持管理されていれ ば災害による道路施設の機能低下は起こらないと考える. したがって, 表 1 の CASE0 では地域内道路, 地域間道路 ともに道路施設の機能低下による所要時間の増加は起こ らない. 一方で, CASE1〜CASE3 では, 地域内道路, 地 域間道路が適切に維持管理されないことにより, 災害に よる道路施設の機能低下が起こる. ここで, 地域内道路, 地域間道路の所要時間の増加を表 3 のように想定する. なお, 地域内道路の機能低下による所要時間の増加率を 示す $50 \%$ という值に特に根拠はない.

表3 道路施設の機能低下による所要時間の増加

\begin{tabular}{|c|c|c|}
\hline & 地域内道路 & 地域間道路 \\
\hline CASE0 & - & - \\
\hline CASE1 & - & $\begin{array}{c}\text { 主要国道または } \\
\text { 高速道路不通 }\end{array}$ \\
\hline CASE2 & $50 \%$ 増 & - \\
\hline CASE3 & $50 \%$ 増 & $\begin{array}{c}\text { 主要国道または } \\
\text { 高速道路不通 }\end{array}$ \\
\hline
\end{tabular}

（8） マークアップ率の設定

道路施設の機能低下は, 地域内移動または地域間移動
のための所要時間を増大させるため, モデル内において は(1)式においてマークアップ率の増加として表現する. ここでは簡単化のため輸送費用として時間費用のみを考 慮し, マークアップ $t^{r s} を(19)$ 式のように設定した. な お, 道路施設の機能低下前の初期状態では, マークアッ プ率をゼロと想定する. また, 生産財価格に占める輸送 費用の割合 $\tau$ の $10 \%$ に特に根拠はない。

$$
t^{r s}=\frac{v T_{1}^{r s}-v T_{0}{ }^{r s}}{v T_{0}{ }^{r s}} \times \tau
$$

ただし， $T^{r s}$ : 地域 $r$ から地域 $s$ に到達するまでの所要 時間， $\tau$ : 生産財価格に占める輸送費用の割合 $(10 \%)$, $v$ : 時間価值, 0,1 : 道路施設の機能低下前後を表寸

\section{3 道路施設の維持管理計画主体と道路施設の重要度, 維持管理の優先順位}

（1）維持管理計画主体が「都道府県」の場合 ここでは，道路施設の維持管理計画主体が都道府県 である場合の道路施設の重要度, 維持管理の優先順位を 明らかにする. 道路施設の重要度, 維持管理の優先順位 を決定する際の基本的な考え方は，道路施設の機能低下 が地域（都道府県）におよぼす経済被害が大きければ, その道路施設に対する重要度, 維持管理の優先順位は高 いということである。つまり, 地域内道路と地域間道路 を考えた場合, 地域がどちらの維持管理に高い重要度, 維持管理の優先順位を置くかは, どちらの道路施設の機 能低下による経済被害が地域にとって大きいかというこ とに依存する. どの地域のどの道路施設の機能低下が, どのような空間被害分布をもたらすかを考察するため, 東京都と鳥取県を例に，空間被害分布の計測結果を紹介 する. 図 3-1〜図 3-3は, 東京都でCASE1〜3を想定し た場合の空間被害分布であり, 図 4-1〜図 4-3 は, 鳥 取県でCASE1〜3を想定した場合の空間被害分布である.

東京都の場合, 図 3-1より, 東京都の地域間道路の 機能低下が起きた場合，その被害は東京都を中心に主に 首都圈に分布することが分かる.また，図 3-2より， 東京都の地域内道路の機能低下が起きた場合, その被害 はほぼ東京都に集中することがわかる，東京都の地域間 道路, 地域内道路ともに機能低下が起きた場合（図 33）では, 被害の水準がCASE1〜3の中で最も高くなるも のの, 被害の分布はCASE1 とほとんど変わらないことが 分かる. したがって, 東京都の地域間道路については, 東京都を中心と寸る周辺地域が協力して維持管理を行い, 地域内道路については基本的には東京都が維持管理を行 うべきであると考えられる。

鳥取県の場合, 図 4-1より, 鳥取県の地域間道路の 機能低下が起きた場合, 島根県に最も大きな被害がもた 


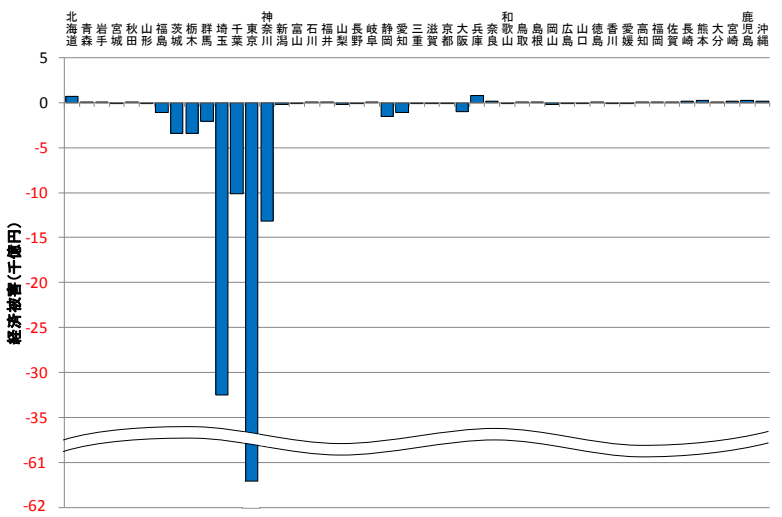

図3-1 空間被害分布(東京都，CASE1)

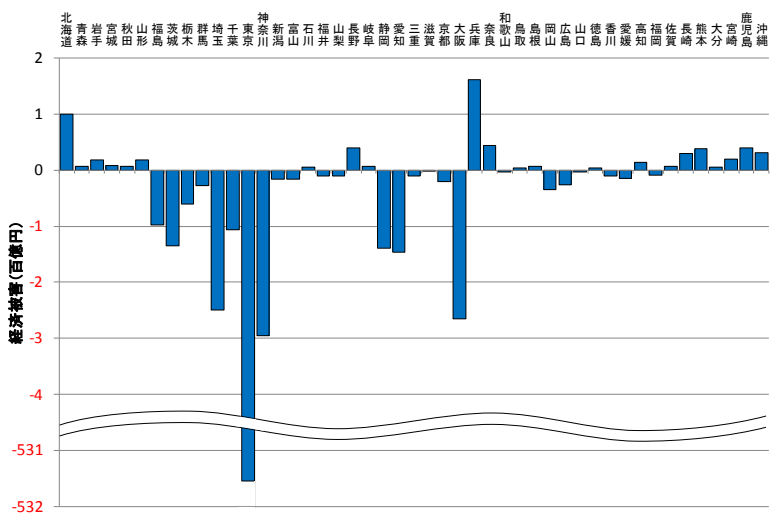

図3-2 空間被害分布(東京都，CASE2)

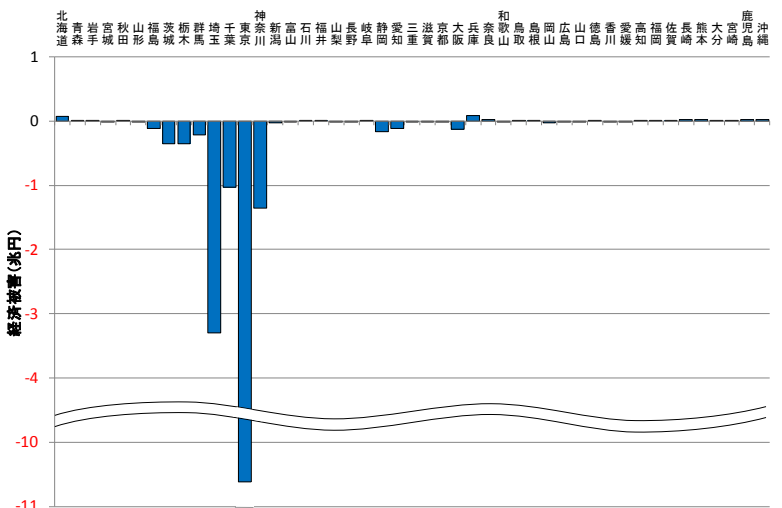

図3-3 空間被害分布(東京都，CASE3)

らされ，さらには鳥取県の周辺地域，鳥取県から比較的 離れた場所にある東京都へも被害が分布することがわか る。これより，鳥取県と島根県の経済的な結びつきの強 さがうかがえる．また，図 4-2より，鳥取県の地域内 道路の機能低下が起きた場合，その被害はほぼ鳥取県に 集中寸ることがわかる，鳥取県の地域間道路，地域内道 路ともに機能低下が起きた場合（図 4-3）では，CASE2 での被害の水準がCASE1よりも大きいため, CASE3では鳥 取県に被害が集中寸る被害分布を示している．したがっ て，鳥取県の地域間道路については，鳥取県を中心とす る周辺地域及び東京都等が協力して維持管理を行い，地 域内道路については基本的には鳥取県が維持管理を行う べきであると考えられる．以上より，東京都においても 鳥取県においても，地域間道路の機能低下は，自地域及

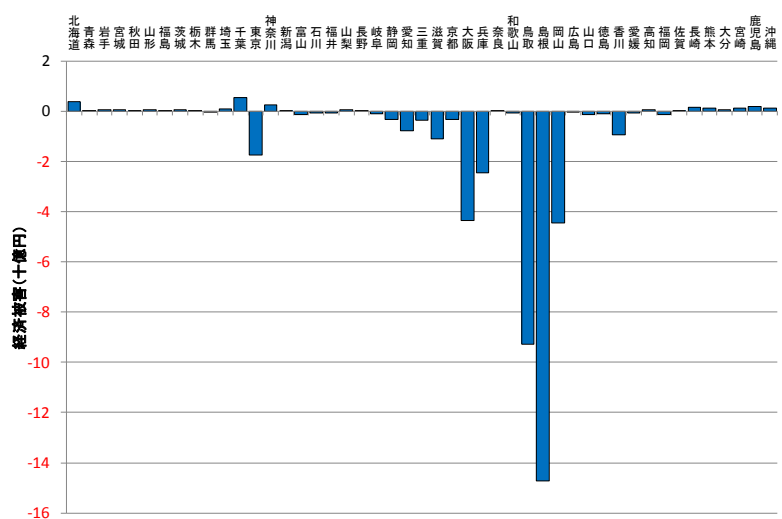

図 4-1 空間被害分布(鳥取県, CASE1)

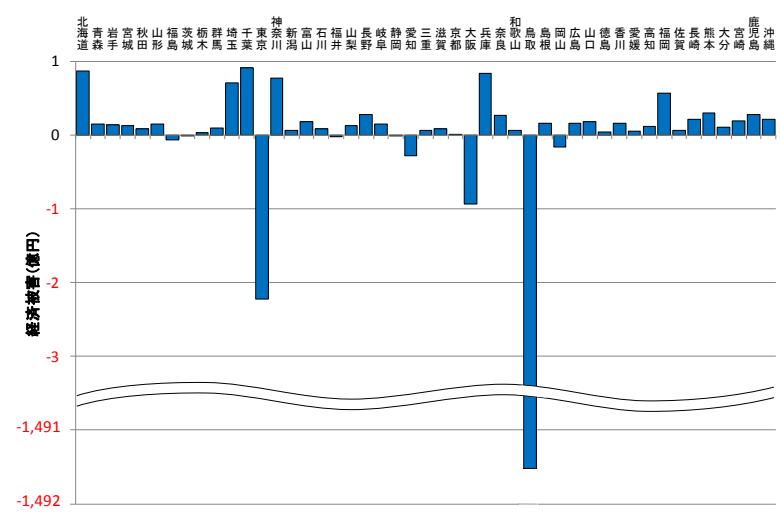

図 4-2 空間被害分布(鳥取県，CASE2)

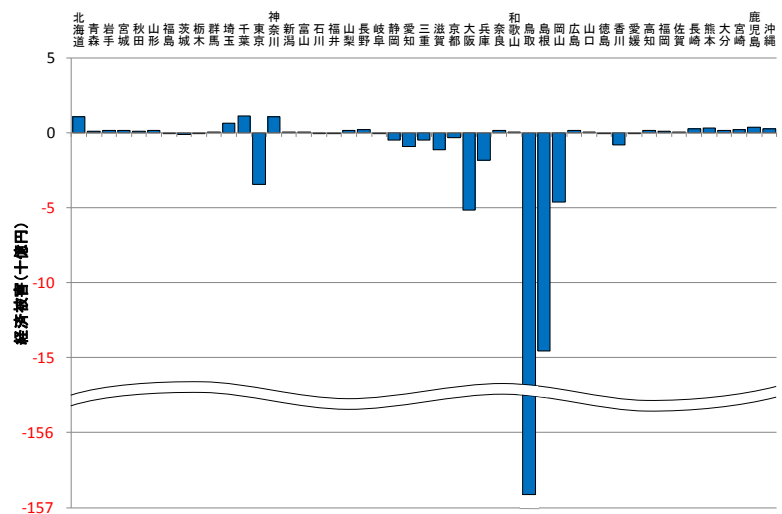

図4-3 空間被害分布(鳥取県, CASE3)

び他地域（主に周辺地域）に被害をもたらす分散型の空 間被害分布を示すことがわかる。一方で，地域内道路の 機能低下は，自地域に集中型の被害をもたらすことがわ かる. 東京都と鳥取県以外の地域についても同様に，空 間被害分布の形状によってどのように維持管理をするべ きかが決まる。つまり，空間被害分布が，当該地域につ いて集中型であれば，基本的には当該地域がその道路施 設の維持管理を行い，分散型であれば周辺またはその他 の地域で協力して維持管理を行うということになるであ ろう.

次に，地域内道路と地域間道路について，地域がごち らに重要度，維持管理に高い優先順位を置くかを考察す るため, SCGEモデルにより計測した経済被害をもとに作 成した経済被害行列を紹介寸る。ここでも，例として東 
表 4-1＼cjkstart東京都における経済被害行列

地域間道路

\begin{tabular}{|c|c|c|}
\hline & $\begin{array}{c}\text { 維持管理 } \\
\text { する }\end{array}$ & $\begin{array}{c}\text { 維持管理 } \\
\text { しない }\end{array}$ \\
\hline $\begin{array}{c}\text { 維持管理 } \\
\text { する }\end{array}$ & ( 0.0兆円, 0.0兆円 ) & （-6.1兆円, -6.7兆円） \\
\hline $\begin{array}{c}\text { 維持管理 } \\
\text { しない }\end{array}$ & ( -5.3 兆円, -0.1 兆円 $)$ & $\begin{array}{c}\text { (-10.6兆円, -6.9兆円 }) \\
\text { 自地域 他地域 }\end{array}$ \\
\hline
\end{tabular}

表4-2＼cjkstart表4-1における割合

地域間道路

\begin{tabular}{|c|c|c|}
\hline & $\begin{array}{c}\text { 維持管理 } \\
\text { する }\end{array}$ & $\begin{array}{c}\text { 維持管理 } \\
\text { しない }\end{array}$ \\
\hline $\begin{array}{c}\text { 維持管理 } \\
\text { する }\end{array}$ & $(0 \%, 0 \%)$ & $(48 \%, 52 \%)$ \\
\hline $\begin{array}{c}\text { 維持管理 } \\
\text { しない }\end{array}$ & $(98 \%, 2 \%)$ & $\begin{array}{c}(61 \%, 39 \%) \\
\text { 自地域 他地域 }\end{array}$ \\
\hline
\end{tabular}

京都と鳥取県の経済被害行列を示すことにする.

東京都の場合，表 4-1より，|a $|>| a_{2} \mid$ であるから， 東京都にとっては地域内道路よりも地域間道路の方が, 重要度が高いといら解釈が考えられる。しかしながら， 道路施設に対して重要度，維持管理の優先順位を考える 場合，維持管理費用を考慮しなければならない，なぜな ら，表 4-1の被害額に維持管理費用を加えた場合，そ れでもなお $\left|a_{1}\right|>\left|a_{2}\right|$ となる保証はなく，場合によって は符号が逆転する可能性があるためである。その場合， 東京都にとっては地域内道路よりも地域間道路の方が, 重要度が高いとは必ずしも言えないであろう。そこで本 研究では，表 4-2のように表4-1を割合で表現するこ とにする，表 4-2では，各CASEにおいて全国にもたら される経済被害を100\%として，自地域に何\%，他地域 に何\%の被害が州着しているかを表現している。ここで， 自地域の被害割合が低いということは，他地域の被害割 合が高く, 他地域に当該道路施設の維持管理を行う動機 が高いことを意味している．このとき，自地域は自発的 に道路施設の維持管理を行う動機が比較的低く，フリー ライダー問題が生じる可能性がある，そこで，表 4-2 のように被害割合をとることで，フリーライダー問題に よる影響を考慮した道路施設の重要度，維持管理の優先 順位を表現することができると考える．表4-2におい てCASE1とCASE2を比較する限り，東京都にとっては，地 域間道路よりも地域内道路を維持管理した方が自地域の 被害割合が低い。したがって，東京都にとっては，地域 間道路よりも地域内道路の方が重要度, 維持管理の優先
表 5-1 鳥取県における経済被害行列

地域間道路

\begin{tabular}{|c|c|c|}
\hline & $\begin{array}{c}\text { 維持管理 } \\
\text { する }\end{array}$ & $\begin{array}{c}\text { 維持管理 } \\
\text { しない }\end{array}$ \\
\hline $\begin{array}{c}\text { 維持管理 } \\
\text { する }\end{array}$ & (0.0百億円, 0.0 百億円 $)$ & (-0.9百億円, -2.9 百億円 $)$ \\
\hline $\begin{array}{l}\text { 維持管理 } \\
\text { しない }\end{array}$ & (-14.9百億円, 0.1 百億円 $)$ & $\begin{array}{c}\text { (-15.7百億円, }-2.6 \text { 百億円 }) \\
\text { 自地域 } \quad \text { 他地域 }\end{array}$ \\
\hline
\end{tabular}

表5-2 表5-1における割合

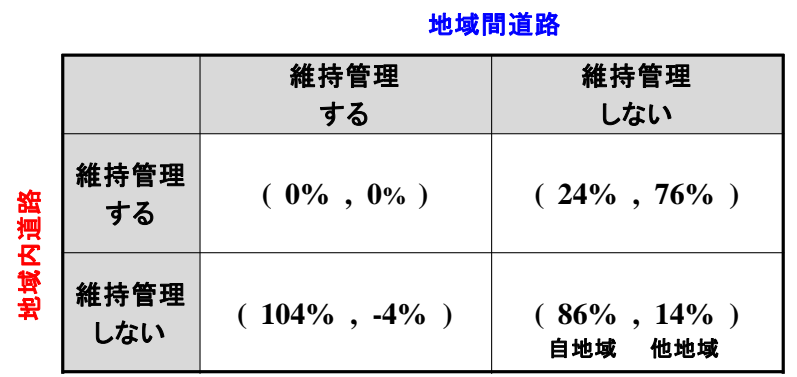

順位が高いということになる.

鳥取県の場合, 表 5-1より $\left|a_{1}\right|<\left|a_{2}\right|$ であり, 表 52 においても $\left|a_{1}\right|<\left|a_{2}\right|$ である. 表 5-2においてCASE1 とCASE2を比較する限り，鳥取県にとっても，地域間道 路よりも地域内道路を維持管理した方が自地域の被害割 合が低い。したがって，鳥取県にとっても，地域間道路 よりも地域内道路の方が重要度, 維持管理の優先順位が 高いということになる．以上より，東京都と鳥取県にと っては，共に地域間道路よりも地域内道路の方が重要度, 維持管理の優先順位が高いといら結論が得られた.

東京都と鳥取県以外の地域についても，同じくCASE1 とCASE2の自地域の被害割合を計測し，各都道府県にと っての地域内道路，地域間道路の重要度，維持管理の優 先順位を表現したものを図 5 に示寸．図 5 では，横軸に CASE1における各都道府県の自地域の被害割合をとり， 縦軸にCASE2における各都道府県の自地域の被害割合を とっている，横軸の割合が高いということは，地域間道 路に対する重要度が高いことを意味しており, 縦軸の割 合が高いということは，地域内道路に対する重要度が高 いことを意味している．前述の分析より，東京都と鳥取 県では，共に地域間道路よりも地域内道路の方が重要度 が高いという結論が得られた。しかしながら，図5にお いて東京都と鳥取県では違いが見られる。それは，地域 内道路に関しては，東京都と鳥取県共に比較的高い重要 度を置いている一方で，地域間道路に関しては，鳥取県 は東京都ほど高い重要度を置いていないという点である。 また，図5より全ての都道府県でCASE1よりもCASE2にお ける自地域の被害割合が大きいことがわかる。したがっ 
て, 全ての都道府県にとって地域間道路よりも地域内道 路の方が重要度が高く, 維持管理の優先順位が高いと考 えられる。

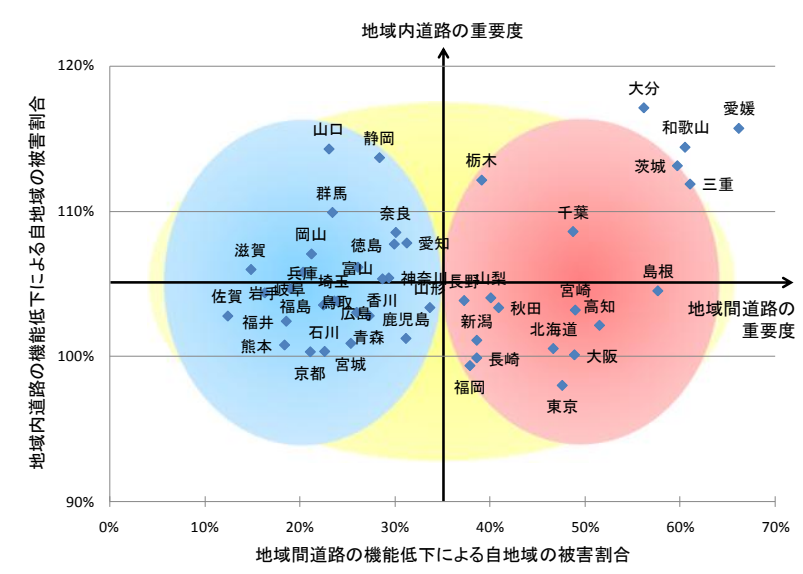

図5 各都道府県にとっての道路施設の重要度

道路施設の維持管理計画主体が都道府県である場合， 本研究により得られた道路施設の重要度, 維持管理の優 先順位の高い順番に維持管理がされると仮定すると, 地 域間道路に対しては維持管理が適切に行われない可能性 がある. 特に，佐賀県や滋賀県等，図 5 の左楕円内のグ ループで，地域間道路に対する維持管理が適切に行われ ない可能性が高い. したがって, この場合, 地域間道路 の維持管理については国がある程度関与寸る必要がある と考えられる。

\section{（2）維持管理計画主体が「国」の場合}

ここでは, 道路施設の維持管理計画主体が国である場 合の道路施設の重要度, 維持管理の優先順位を明らかに する. 優先順位を決定する際の基本的な考え方は, 道路 施設の機能低下が一国全体におよぼす経済被害が大きけ れば，その道路施設に対する維持管理の優先順位は高い ということである.つまり，表 2 の経済被害行列におい て， $a_{i}$ と $b_{i}$ を足し合わせた值の大小によって，国にと っての道路施設の重要度, 維持管理の優先順位を決定す る. CASE1 とCASE2における各都道府県の道路施設の機能 低下が，全国にもたらす経済被害（都道府県別経済被害 の合計）を図6に示寸.また, CASE3における各都道府 県の道路施設の機能低下が，全国にもたらす経済被害 (都道府県別経済被害の合計) を図 7 に示寸.

図6より，道路施設の機能低下が全国にもたらす経済 被害額は，東京都の地域間道路の機能低下による影響が 最も大きいことが分かる. したがって, 地域内道路, 地 域間道路ともに維持管理の費用が等しいと仮定すると, 道路施設の維持管理計画主体が国である場合，国にとっ

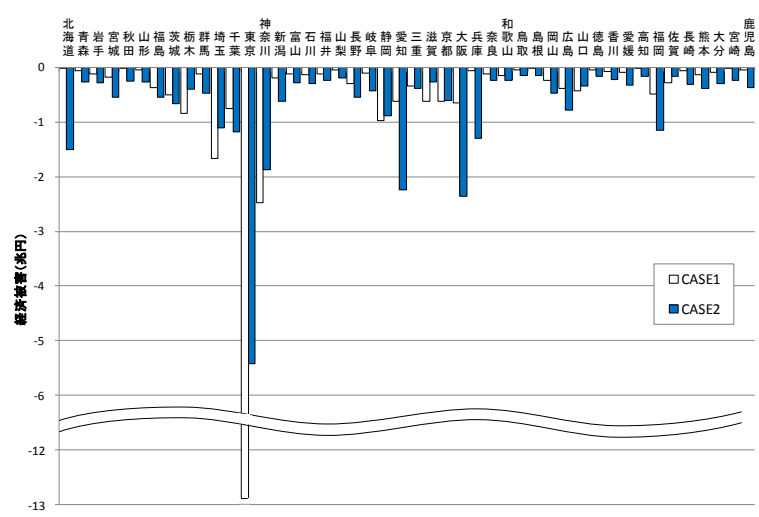

図6 国にとっての道路施設の重要度 (CASE1, 2)

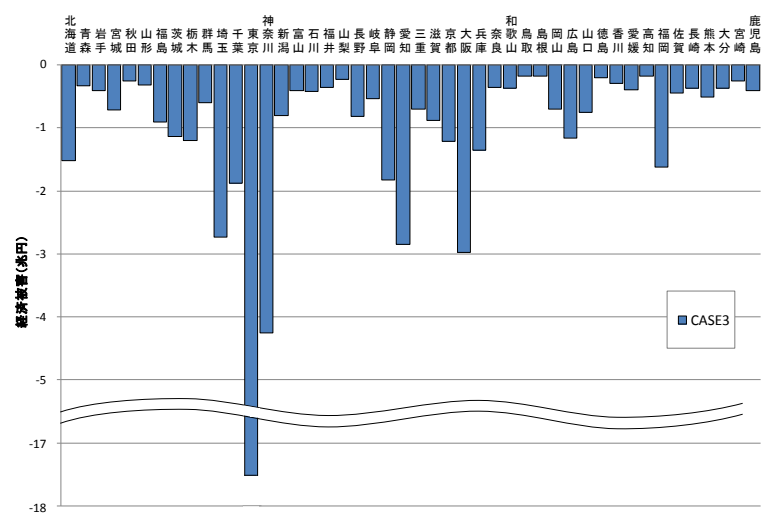

図7 国にとっての道路施設の重要度 (CASE3)

ては東京都の地域間道路に対する維持管理の優先順位が 最も高いと考えられる. また, 図 7 より, 各都道府県が 有する道路施設の内, 東京都が有する道路施設がわが国 にとって最も重要度が高いことがわかる. 東京都等の地 域間の経済取引が活発である地域ほど，地域間道路の機 能が低下寸ると全国にもたらされる経済被害は大きいと 考えられる，地域間の経済取引が活発である地域は，経 済規模が大きいと考えられるため，道路施設の維持管理 計画主体が国レベルである場合, 道路施設の維持管理は 経済規模が大きい地域から優先的に行うという結論とな ると考えられる. したがって, 維持管理が後回しになる 経済規模が小さい地域に対しては，その地域が最低限の 維持管理を行えるように，国が維持管理費用を補助する など，対策をとる必要があると考えられる.

\section{4 おわりに}

本研究では, わが国の主要国道, 高速道路レベルの道 路ネットワークを想定し, SCGEモデルを用いて, 道路施 設の機能低下が各都道府県の自地域および他地域にもた らす経済被害を計測した。また，道路施設の維持管理計 画主体として, 都道府県と国を想定し, 維持管理計画主 体別に道路施設の重要度, 維持管理の優先順位を検討し た. その結果, 道路施設の維持管理計画主体が都道府県 
の場合，各都道府県にとっては，地域間道路よりも地域 内道路の方が重要度が高いことがわかった. また，道路 施設の維持管理計画主体が国の場合, 国にとっては, 経 済規模が大きな都道府県が有寸る道路施設の重要度が高 いことがわかった. ただし, 信頼性のある分析結果を得 るためには, 地域内道路の機能低下による所要時間の増 加率, 生産財価格に占める輸送費用の割合のように特に 根拠のない值を用いている指標や，代替弾力性の設定( に関して感度分析を行う等, 課題が挙げられる.

現在，わが国では地方分権化の流れにより中央から 地方一の権限委譲が進みつつある. また, 近年各地域の 自治体は厳しい財政状況に直面している. さらには, 過 去に建設された道路施設の更新時期が迫っており, 維持 管理・修綁費用が今後増えていくことが予測されている. このような状況では, 経済活動において重要な道路施設 であっても, 財源不足などにより適切に維持管理が行わ れないことがあり得る．したがって，経済活動を支える 重要な道路施設を見極め, 優先的に維持管理を行うこと が，今後ますま寸重要になってくるであろう.
参考文献

1）小池淳司・上田孝行 : 大規模地震による経済的被害の 空間的把握-空間的応用一般均衡モデルによる計量厚 生分析-, 防災の経済分析, 勁草書房, 第8章, pp. 136-149, 2005.

2）小池淳司・右近崇: 新潟県中越地震における磐越道 上信越道のリダンダンシー効果, 高速道路と自動車, Vol. 49, No. 7, pp. 17-26, 2006.

3）土屋哲・多々納裕一・岡田憲夫 : 空間応用一般均衡厂 プローチによる東海地震の警戒宣言時の交通規制に伴 う経済損失の評価, 地域安全学会論文集, No. 5, pp. 319-325, 2003.

4）土屋哲・多々納裕一：SCGEモデルを用いた基幹交通網 に関する地震リスクのパブリックマネジメント，社会 技術研究論文集，Vol.2，pp. 228-237， 2004.

5）宮城俊彦・石川良文・由利昌平・土谷和之 : 地域内産 業連関表を用いた都道府県間産業連関表の作成，土木 計画学研究・論文集, Vol. 20, No. 1, pp. 87-95, 2003.

6）土谷和之・秋吉盛司・小池淳司 : SCGEモデルにおける 地域間交易の代替弾力性に関する検討, 応用地域学会 (ARSC) 第19回研究発表会講演概要, 2005.

\section{防災計画のための空間被害分布分析*}

小池淳司** • 山田勝也****

災害による道路施設への被害は，直接被害のみならず間接被害といら形で全国に波及する。したがって， 道路施設の維持管理を適切に行うことは，災害時の道路施設の機能低下による経済被害を軽減する上で重要 である.また，道路施設の維持管理計画主体によって維持管理の優先順位は異なると考えられるため，どの 主体が維持管理を行うかは維持管理計画を決定する上で重要な要素となりえる. 本論文では，わが国の道路 施設を対象に，それらの機能が低下した場合の経済への影響を空間的応用一般均衡（SCGE）モデルにより評 価することで，道路施設の重要度，維持管理の優先順位を検討した．また，維持管理計画主体として都道府 県と国を想定した.

\section{Spatial Economic Damage Assessment for Disaster Prevention Plan*}

By Atsushi KOIKE** - Katsuya YAMADA***

The damage to road infrastructure by a disaster has impacts on whole of nation. Therefore, it is important to implement a proper road maintenance management to reduce the damage. In addition, the priority level of the road infrastructure maintenance management is changed with the project implementing body. Therefore, it is an important element that who implements a road maintenance management. In this paper, we analyzed the priority level of road infrastructure in Japan to measure the damage by spatial computable general equilibrium (SCGE) model. We also assumed local prefectural governments and the national government as the project implementing body. 